\title{
For the $60^{\text {th }}$ birthday of Professor Jozef Halgoš
}

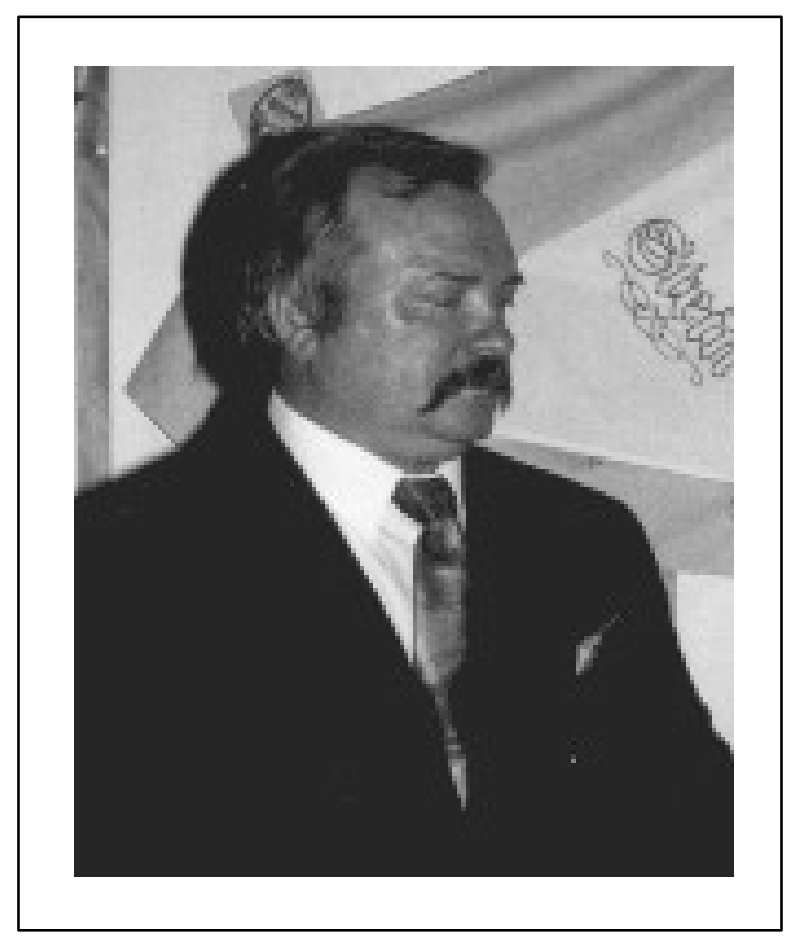

November 23, 2006 marked the 60th birthday of a distinguished Slovak scientist and University lecturer, biologist, parasitologist and ecologist.

Jozef Halgoš was born in Trenčín Soblahov. After completing his high school education in 1965, he studied at the Faculty of Natural Science of Commenius University, specialising in biology and chemistry, with particular attention to zoology. Having completed his studies in 1970, he was admitted into the Department of Systematic and Ecological Zoology of his Alma mater as a Teaching and Research Assistant. In 1974 he joined the Zoological Institute of the same faculty, taking up the position of Head of the Department of Parasitology, followed later as the Deputy Director and during 1994 to 1996 he served as the Director of the Institution. He remained in this position even after the Institute had transformed into the Institute of Ecology and after its renaming the Department of Ecology in 1996 he was appointed Head of the Department.

In 1980 he defended his first-degree thesis at the Parasitological Institute of CSAS in the field of Parasitology, in 1989 he defended his doctoral thesis at the Zoological Institute of AS in Leningrad, having been awarded the degree of Doctor of Sciences. In 2000 he attained the habilitation, and in 2002 he was appointed as Professor in the field of Ecology.

Immediately after accepting a position at Commenius Uni- versity he had actively involved himself in the teaching process. He supervised courses in Invertebrate Zoology, Parasitology, and practicals in Diagnostic methods in Parasitology, he also lectured in Medical Geography and for 20 years he supervised courses and practicals in Tropical Medicine, organized by the Institute for the further education of doctors of medicine and pharmacy. He has supervised the diploma theses of Slovak and foreign students, and mentored many post-doctoral students in Zoology and Parasitology. Currently he mentors several students in the scientific discipline of Ecology. He lectures on Parasitology for ecologists, Evolutionary Parasitology, Medical Entomology, Diagnostic Methods in Parasitology, and leads specialized lectures for Ph.D. students in Ecology of Diptera, and part of the course is on the Ecosystems of the Earth.

It is not an easy task to characterise the extensive scientific and publication activities of Jozef Halgoš. He is engaged in various research projects, in particular in the field of Biology and Ecology of blood-sucking dipterans (mosquito's and black flies) and other important parasitic species. He has participated in 21 expert studies and projects on practice and monitoring, including two PHARE projects. He has published more than 12 scientific works in journals at home and abroad and numerous popular scientific contributions too. He also served as a member of the Advisory Board for the Research on Human Ochocerciasis in Africa and for Greek Fauna research. At present, he is engaged in international co-operation between Department of Ecology of the CU, and the Department of Ecology of the Sileasian University in Katowice and Zoological Institute of RAS in St. Peterburg. He was a member of several scientific expeditions, e.g. in Mongolia, Vietnam, Africa and in the Middle East, Morocco and Greece. Beyond all these brilliant professional achievements, Professor Halgoš is a fascinating personality who always displays originality and mastery of scientific experience and has a great team spirit. In recognition for his long-term pedagogical and scientific activities, he has received many awards, such as the Medal of Professor Hovorka, the Medal of Stanislav Prowázka, the Medal of Karol Brančík and the Medal of the Faculty of Natural Sciences of the CU. He is also a holder of the Mongolia State Award.

On behalf of all students, former and current and fellows, colleagues and friends, both past and present, we would like to take this opportunity on the occasion of his $60^{\text {th }}$ birthday and thank him for his scholarship, leadership and friendship. We wish him happiness, contentment and success both at work and in his personal life for many years to come. 